\title{
Measuring the Effectiveness and Validity of Employees Annual Confidential Report (ACR) and Its Applicability: A Case Study of Abdul Wali Khan University, Mardan
}

\author{
IHTESHAM KHAN \\ Assistant Professor and PhD Scholar, Institute of Business Studies and Leadership \\ Abdul Wali Khan University, Mardan \\ ihtishamkhan@awkum.edu.pk \\ DR. ADNAN AHMAD \\ Assistant Professor, Institute of Business Studies and Leadership \\ Abdul Wali Khan University, Mardan \\ adnankhattak@awkum.edu.pk \\ DR.SHAHID JAN \\ Associate Professor, Institute of Business Studies and Leadership \\ Abdul Wali Khan University, Mardan \\ shahidjan@awkum.edu.pk
}

\begin{abstract}
ACR system is being used as a performance management and evaluation tool in AWKUM for the last five years since its inception as a Public sector university in KPK, Pakistan. The main purpose of this study is to find out that whether ACR system do fulfill the requirement of an effective and efficient Performance evaluation and management tool. What employees think of this system? As any excellent performance management system plays a very vital role in the success of any organization.
\end{abstract}

Keywords: Annual Confidential Report, Performance Management System

\section{Introduction}

Every organization uses a performance evaluation and management system to measure the performance of the employees within the organization. These performance evaluation systems help in finding out that whether the employees are working as per the requirement they are being asked for. The main purpose of the employee's performance evaluation system is to support the company strategic aim. It's a scientific approach to ensure that the employee's efforts are linked with the organizational goal. In Pakistan mostly Annual Confidential Report (ACR) is used as performance evaluation tool. ACR system is based on a confidential report that is only being filled by the supervisor of the employee. Mostly ACR is used in public sector organizations in Pakistan while the private sector is moving towards proper performance management systems (PMS). PMS helps organization to give proper feedback, career management, proper training and development to their employees. 


\subsection{Problem Statement}

To measure effectiveness and validity of employees Annual confidential Report as a performance evaluation system used by AWKUM and critical analysis of its ability to measure the employees performance.

\subsection{Objectives of the Research}

The following are the objectives of the research.

- To measure effectiveness and validity of employees Annual confidential Report as a performance evaluation system used by AWKUM.

- To critically evaluate the current system of ACR implemented.

\section{Literature Review}

ACR system is being used to measure the performance of the employees. So that proper feedback is being given to the employees. After that proper training session is being arranged if any deficiency is there. The main purpose of this research is to find that ACR system is serving that purpose or not? Feedback plays a vital role in managing the performance of nay employee in the organization. Without a proper feedback an employee cannot judge its performance. Feedback must not be only from the supervisors it should be from the peers as well as from the subordinates. By using proper feedback system in the organization employee can revisit its performance. What mistakes he/she committed that my lack him in his performance (Bandura \& Hackman, 1977). Feedback normally happens through communication with each other but proper system can be used for proper evaluation of the employees performance through feedback about their performance in the organization (Yeager, 1985). Feedback is a very important part in an organization to the employees about their performance. Without a proper feedback how the employees know that how they performed during the year. The employees will be thinking that are they doing ok or they need to improve their performance. For that organization must have a proper feedback system so that they can have a check on the employees that our performance is properly measured and evaluated and we are given proper feedback that how we are performing (Rabin, 1985).

In many organizations is using 360 degree feedback. In 360 degree feedback information is gathered about the employees from all the other people whom have an interaction with employees means supervisors, peer, subordinates. This gives a clear picture to the organization that where the employee stands. Through proper feedback organization can have a proper look that whatever goal was set for the specific employee was achieved or not. So it means that goal setting should be linked to feedback. Porter and steers (1974) said that when the organizations connect goals with feedback then the employee will have a clear picture that he/she is doing and what is expected of him. Employee will then be told from time to time that whether he/she is on track or require any improvement. After proper feedback then if required employee can be properly trained and developed for the goal that is being set by the organization from him/her to perform properly. If an employee is lacking behind in any competency that require proper training then without proper training feedback has no effect on the employee. So with feedback proper training is also an important factor to consider in employees performance to increase (Belilos, 1997). With training employee can have a belief of development that he/she can now bitterly serve the organization but in public sector 
organization training is taken only as a formality. In the recent days career management is a very important concept in employee's job commitment towards organizations. Every employee plan their career and if organization help them to manage their career goal and set a career path then they start to show their commitment towards the organization (Philips, 1982). Once an employee is satisfied that organization is taking care of his/her career management then he/she taking interest in developing skills to set career goals. Many human resource experts have considered career management and career development important for employee's motivation and commitment towards organization (Hall \& Associates, 1986; London \& Mone, 1987). Career management can be divided into three different steps. Step one is career exploration where the employee wants to explore his/her career he/she wants to pursue. Her employee starts to explore career that can fit his/her skills, aptitude and abilities. Employees match his/her skills with the job requirement (Philips, 1982). After career exploration then the stage of career development comes. In career development the employee sets the goals for his/her career. Career goals includes rise in salary, promotion and acquisition of skills that has positive influence on the overall job performance of the employee. In the next step employee prepare strategies for the career goals achievement (Gould \& Pemly, 1984). Those employees whose career current job position is more closer to the career goal they set for themselves the more they go for the career exploration because they have already achieved what they strived for now they go for higher career goals.

These career management strategies help employees to keep themselves closer to the organization. Even it helps the super visors to allow them get the employee on course for the job they require of them. Supervisors can couch their subordinates by telling them which course of action takes them to their career goals. Couching is an ongoing process between the supervisors and the employees working under him. It is very important that a trust culture should be there between the supervisors and the employees (Farr \& Jacobs, 2006). Both in public and private sector organizations supervisors should take employees on board. They should teach them and coach them by changing their behavior and setting directions for the employees to set their course of action (Peterson, 2006). Management by objective is new concept that is taking place in the current organizations, here the employees and management come together and gets agree about certain objectives (Drucker, 1954). There are two types of concept about employees working in the organization. One employee dislikes work and therefore strict rules should be set to take work from them. Other employee likes work they feel satisfaction when perform a task (McGregor, 2005). Management by objective requires full support of the supervisors and employees working under them. It can be a very effective tool in public sector organizations. Through it supervisor will know what they have to do and expect the employees to perform their task better as Management by objective only be implemented after both the supervisors and employees shoe their commitment to it.

\subsection{Hypothesis}

$\boldsymbol{H}_{0}: A C R$ is not an effective tool used to measure the performance of the employees in AWKUM.

$\boldsymbol{H}_{1}:$ ACR is an effective tool used to measure the performance of the employees in AWKUM. 


\section{Research Methodology}

\subsection{Sampling}

The target segment was officers of AWKUM. Data was collected to assess the effectiveness of the ACR as performance evaluation system. The samples were randomly selected. Sample size was 40 different officers of AWKUM.

\subsection{Questionnaire Design}

Primary data had been collected by using questionnaire. Likert scale questionnaire was used that has options from 1 to 5 . 1 show strongly disagrees and 5 shows strongly agree. To analyze mode and median were used as an analysis tool.

\subsection{Procedure}

Questionnaires were distributed among sample in AWKUM. After 3 days questionnaires were collected from the respondents.

\section{Results and Analysis}

Based on the questionnaire analysis was done using mode and median as an analysis tool. Results compiled on the basis of these tests for each question of the questionnaire are given below:

Qno.1The current ACR system has a significant impact on my career development and career growth.

\section{Statistics}

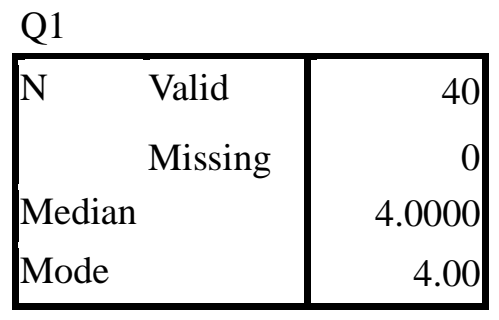

\begin{tabular}{|c|c|c|c|c|c|c|}
\hline \multicolumn{7}{|c|}{ Q1 } \\
\hline & & & Frequency & Percent & Valid Percent & $\begin{array}{l}\text { Cumulative } \\
\text { Percent }\end{array}$ \\
\hline \multirow[t]{6}{*}{ Valid } & Strongly Agree & & 1 & 2.5 & 2.5 & 2.5 \\
\hline & Agree & & 2 & 5.0 & 5.0 & 7.5 \\
\hline & $\begin{array}{ll}\text { Neither } & \text { Agree } \\
\text { Disagree } & \end{array}$ & Nor & 2 & 5.0 & 5.0 & 12.5 \\
\hline & Disagree & & 26 & 65.0 & 65.0 & 77.5 \\
\hline & Strongly Disagree & & 9 & 22.5 & 22.5 & 100.0 \\
\hline & Total & & 40 & 100.0 & 100.0 & \\
\hline
\end{tabular}


Q1

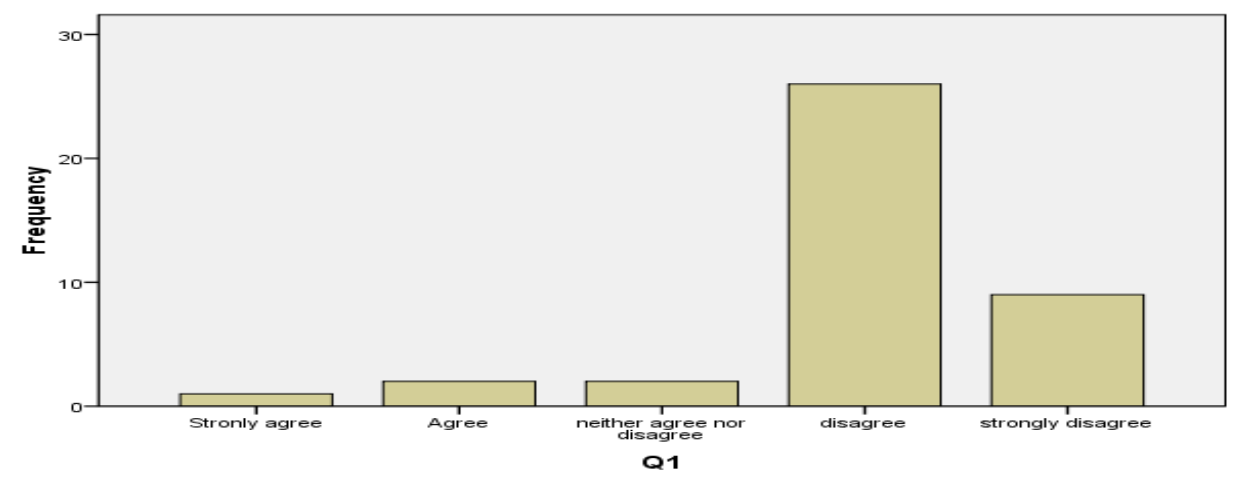

Based on the analysis given above it is clear that the current ACR system has no significant impact on the employee's career development and growth as maximum employees had disagreed with the fact.

Qno.2. The current ACR system gives me recognition for giving outstanding

\section{Statistics} performance.

\begin{tabular}{|lr|r|}
\hline N $\quad$ Valid & 40 \\
\multicolumn{2}{|l|}{ Missing } & 0 \\
Median & & 4.0000 \\
Mode & & 4.00 \\
\hline
\end{tabular}

\begin{tabular}{|c|c|c|c|c|c|c|}
\hline \multicolumn{7}{|c|}{ Q2 } \\
\hline & & & Frequency & Percent & Valid Percent & $\begin{array}{c}\text { Cumulative } \\
\text { Percent }\end{array}$ \\
\hline \multirow[t]{6}{*}{ Valid } & Strongly Agree & & 2 & 5.0 & 5.0 & 5.0 \\
\hline & Agree & & 1 & 2.5 & 2.5 & 7.5 \\
\hline & $\begin{array}{ll}\text { Neither } & \text { Agree } \\
\text { Disagree } & \end{array}$ & Nor & 5 & 12.5 & 12.5 & 20.0 \\
\hline & Disagree & & 21 & 52.5 & 52.5 & 72.5 \\
\hline & Strongly Disagree & & 11 & 27.5 & 27.5 & 100.0 \\
\hline & Total & & 40 & 100.0 & 100.0 & \\
\hline
\end{tabular}




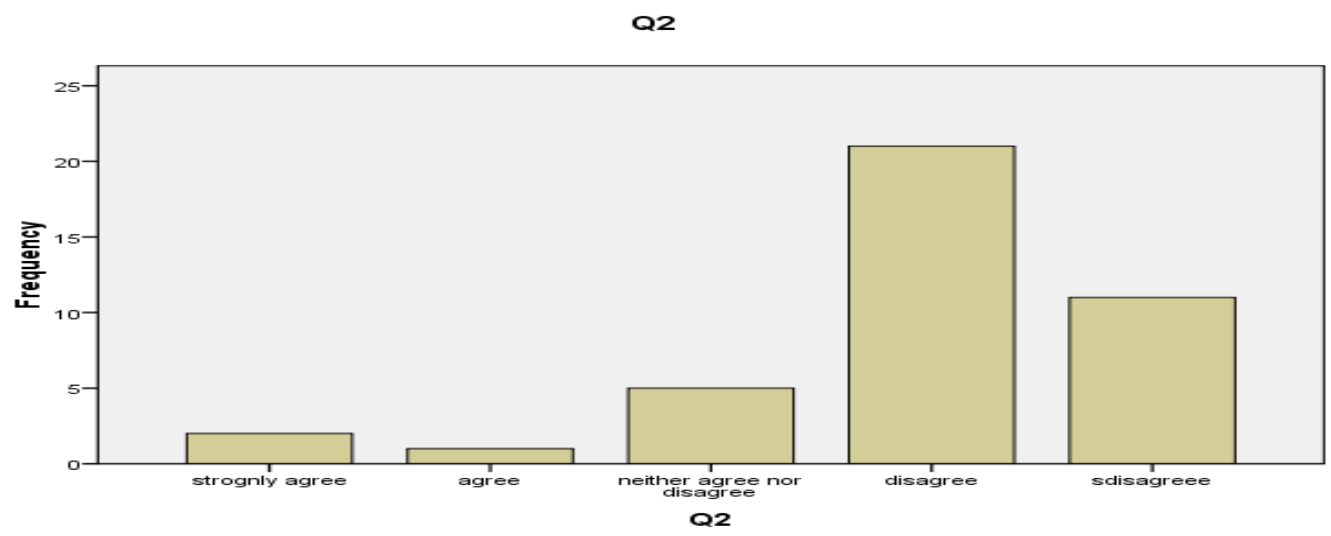

The above analysis shows that maximum employees are not being recognized for their outstanding performance. Whether they perform poor or best there will be no incentive for them for outstanding performance.

Qno.3. My pay and rewards are fairly and equitably linked to my performance in the current ACR system.

Statistics

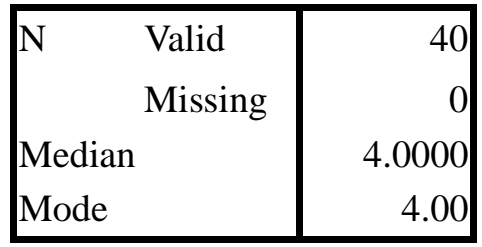

\begin{tabular}{|ll|r|r|r|r|}
\hline \multicolumn{1}{|c|}{ Q3 } \\
\hline Valid & Strongly Agree & Prequency & Percent & Valid Percent & $\begin{array}{c}\text { Cumulative } \\
\text { Percent }\end{array}$ \\
& 4 & 10.0 & 10.0 & 10.0 \\
& Agree & 5.0 & 5.0 & 15.0 \\
Neutral & 2 & 10.0 & 10.0 & 25.0 \\
Disagree & 4 & 60.0 & 60.0 & 85.0 \\
Sdisagree & 24 & 15.0 & 15.0 & 100.0 \\
Total & 6 & 15.0 & 100.0 & \\
\hline
\end{tabular}




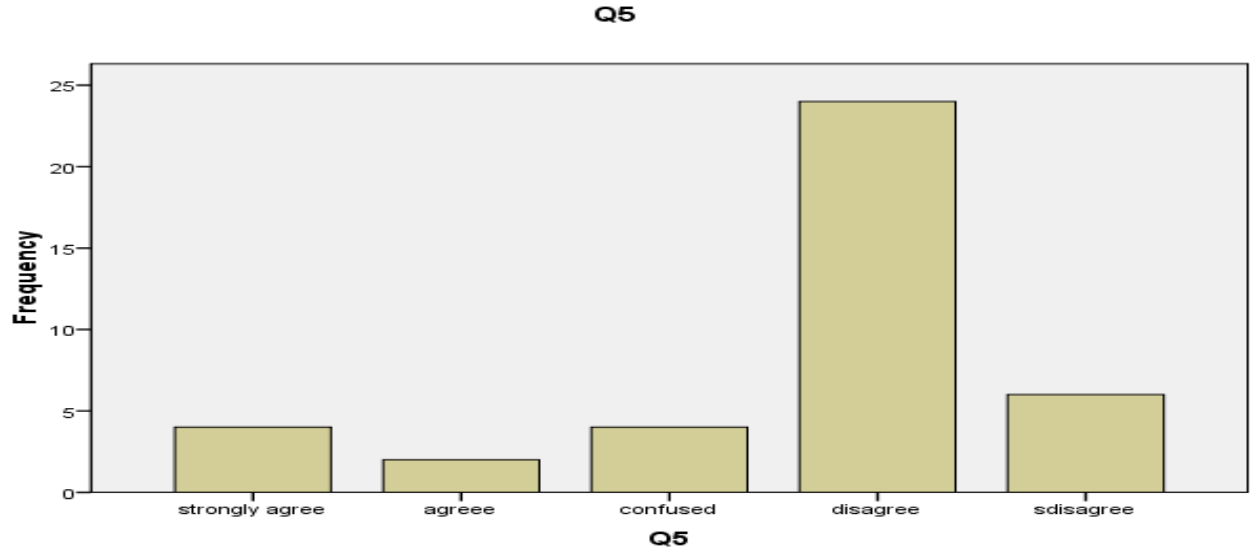

The above analysis show that in AWKUM pay and rewards are not linked to the performance of the employees ACR is not being used to gather data and put in the cupboard of the registrar office. Pay and salaries are being given through a set formula. Both the high performer and the low performer arte treated in the same way.

Qno.4. I am more motivated and produce the better expected results in the current performance evaluation system (ACR).

\section{Statistics}

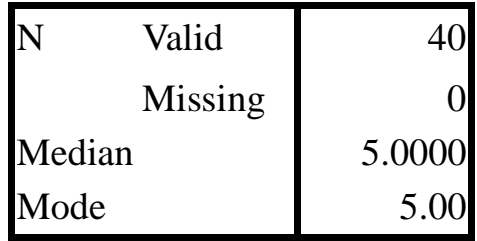

\begin{tabular}{|ll|r|r|r|r|}
\hline & & Frequency & Percent & Valid Percent & $\begin{array}{c}\text { Cumulative } \\
\text { Percent }\end{array}$ \\
\hline Valid Agree & 7 & 17.5 & 17.5 & 17.5 \\
& Neither Agree Nor & 3 & 7.5 & 7.5 & 25.0 \\
Disagree & & 7 & 17.5 & 17.5 & 42.5 \\
Disagree & 23 & 57.5 & 57.5 & 100.0 \\
Strongly Disagree & 40 & 100.0 & 100.0 & \\
Total & & & \\
\hline
\end{tabular}


Q7

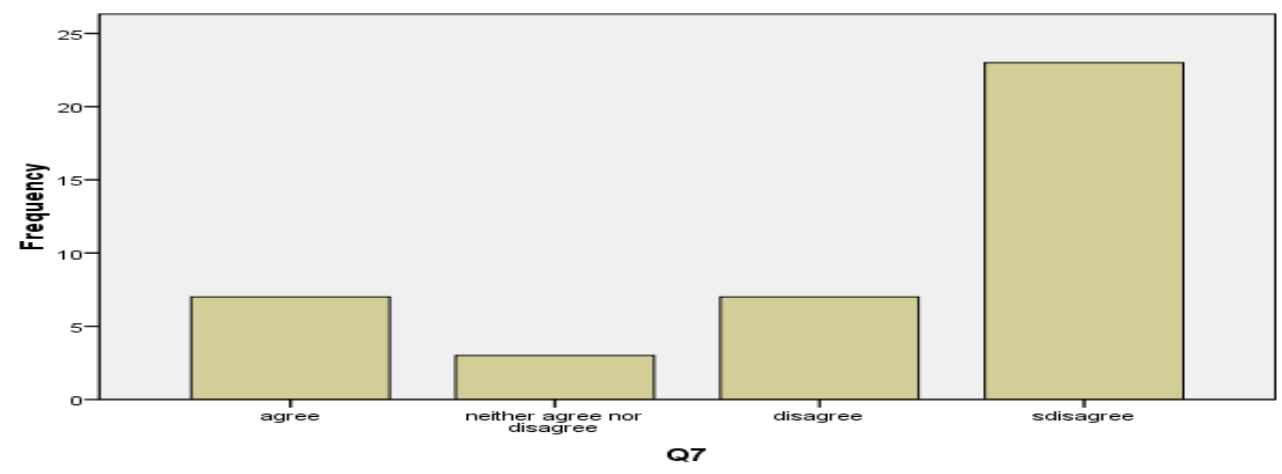

The analysis above shows that in the current ACR system employees don't show there motivation because they know that ACR is not a tool that can give him the edge if he perform well. So it can't be a tool with which an employee can be motivated.

Qno.5. Supervisors give me advice in the current ACR system about my tasks.

Statistics

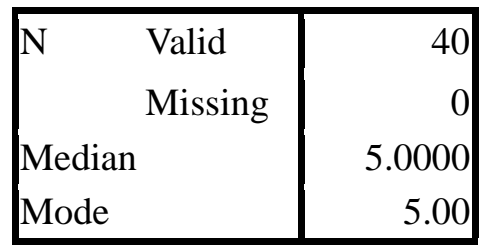

\begin{tabular}{|ll|r|r|r|r|}
\hline & & & \\
& & Frequency & Percent & Valid Percent & $\begin{array}{c}\text { Cumulative } \\
\text { Percent }\end{array}$ \\
\hline Valid Strongly Agree & 1 & 2.5 & 2.5 & 2.5 \\
& Agree & 4 & 10.0 & 10.0 & 12.5 \\
Neither Agree nor & 6 & 15.0 & 15.0 & 27.5 \\
Disagree & & 3 & 7.5 & 7.5 & 35.0 \\
Disagree & 26 & 65.0 & 65.0 & 100.0 \\
S. Disagree & 40 & 100.0 & 100.0 & \\
Total & & &
\end{tabular}




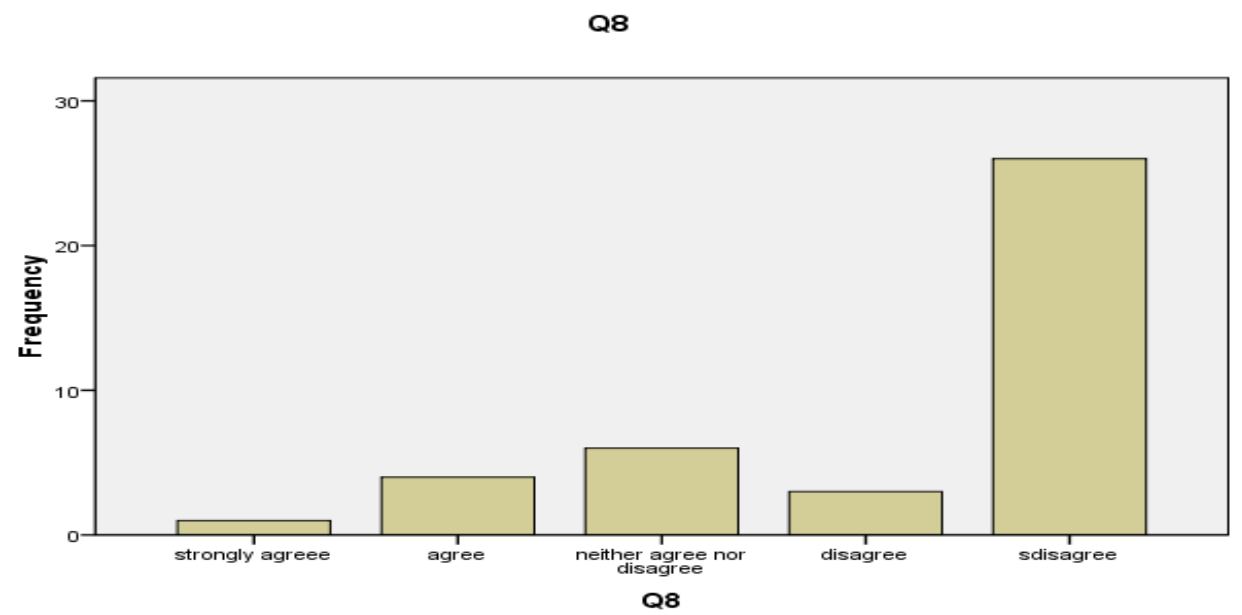

The analysis above shows that ACR system and the supervisors advice about the employee has no connection between each other. The reason is that the supervisors only fill the ACR forms of the employee and is of no concern about sharing it with the employee. It means that ACR system is a total failure.

Qno.6. I am satisfied with the fact that my performance in current ACR system is evaluated at the end of the period and not the whole year.

Statistics

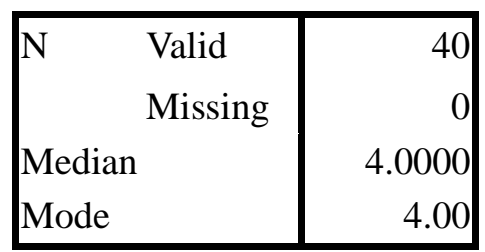

Q6

\begin{tabular}{|c|c|c|c|c|c|c|c|}
\hline & & & & Frequency & Percent & Valid Percent & $\begin{array}{c}\text { Cumulative } \\
\text { Percent }\end{array}$ \\
\hline \multirow[t]{5}{*}{ Valid } & Agree & & & 3 & 7.5 & 7.5 & 7.5 \\
\hline & $\begin{array}{l}\text { Neither } \\
\text { Disagree }\end{array}$ & Agree & Nor & 2 & 5.0 & 5.0 & 12.5 \\
\hline & Disagree & & & 33 & 82.5 & 82.5 & 95.0 \\
\hline & S .Disagree & & & 2 & 5.0 & 5.0 & 100.0 \\
\hline & Total & & & 40 & 100.0 & 100.0 & \\
\hline
\end{tabular}




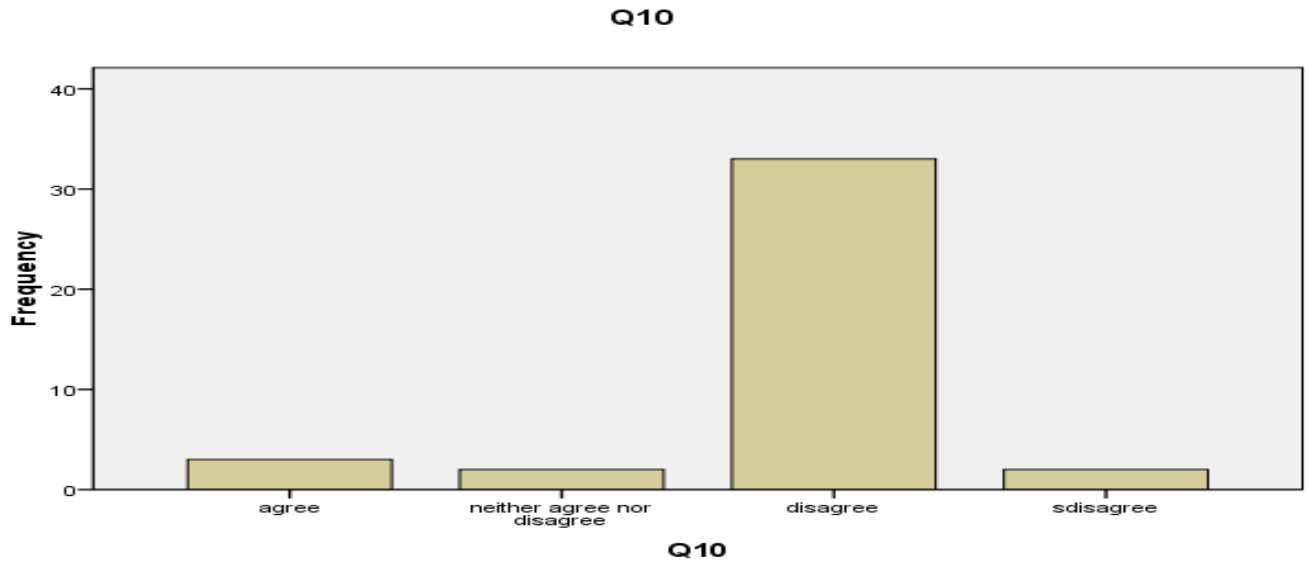

Above Analysis shows that in ACR system employees are only judged at the end of the period. If an employee had worked hard for eleven months and didn't performed well in the end month or the supervisor haven't got satisfied with the employee in the end month then his/her ACR will poor. So an employee should be judged throughout the year not only in the last month.

Qno.7. The current ACR system is free from any kind of biasness of supervisors.

\section{Statistics}

\begin{tabular}{|c|c|c|}
\hline N & $\begin{array}{l}\text { Valid } \\
\text { Missing }\end{array}$ & 40 \\
\hline & & 4.0000 \\
\hline & & 4.00 \\
\hline
\end{tabular}

\begin{tabular}{|ll|r|r|r|r|}
\hline & & & \\
& & Qrequency & Percent & Valid Percent & $\begin{array}{c}\text { Cumulative } \\
\text { Percent }\end{array}$ \\
\hline Valid & Strongly Agree & 2 & 5.0 & 5.0 & 5.0 \\
Agree & 3 & 7.5 & 7.5 & 12.5 \\
Neither Agree Nor & 3 & 7.5 & 7.5 & 20.0 \\
Disagree & & 28 & 70.0 & 70.0 & 90.0 \\
Disagree & & 10.0 & 10.0 & 100.0 \\
S. Disagree & 4 & 100.0 & 100.0 & \\
Total & 40 & & \\
\hline
\end{tabular}




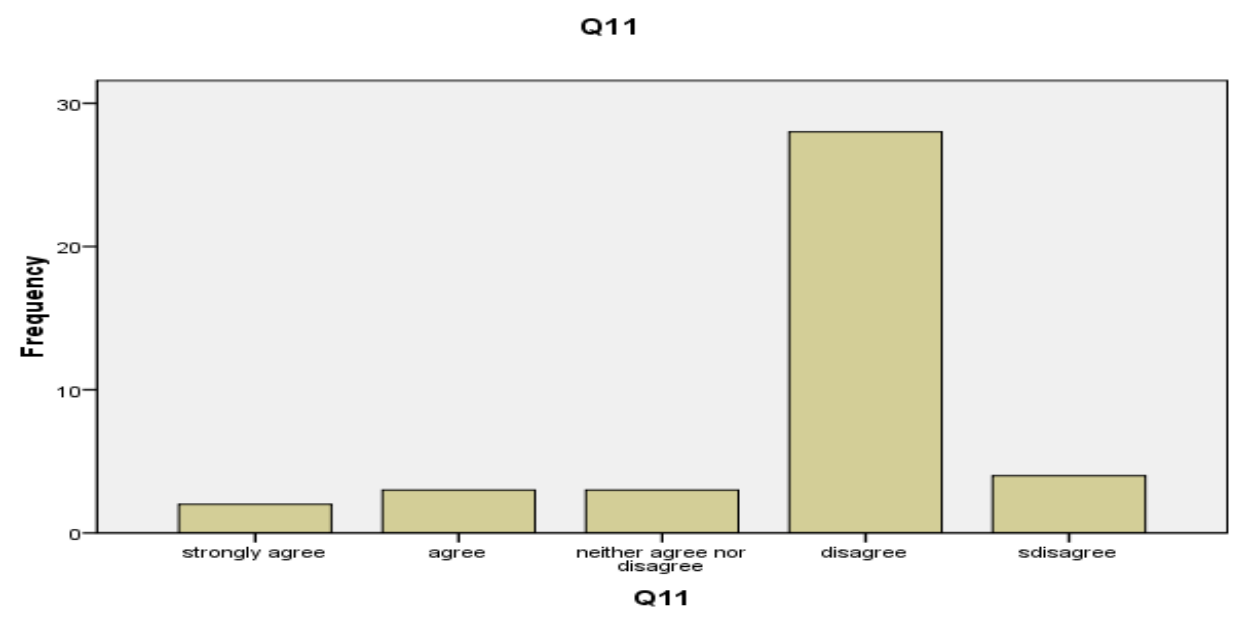

In current ACR system supervisors are all in the all. They are the one who fill ACR form for employees. If the supervisor is biased then he/she can give false information about the employee's performance during the year. Not only that the employee didn't know even whatever is being written about his/her performance during the year as it is being kept confidential.

Qno.8 The current ACR system takes my feedback from the peers and students about my performance.

\section{Statistics}

\begin{tabular}{|c|c|c|}
\hline $\mathrm{N}$ & $\begin{array}{l}\text { Valid } \\
\text { Missing }\end{array}$ & 40 \\
\hline & & 4.0000 \\
\hline & & 4.00 \\
\hline
\end{tabular}

\begin{tabular}{|c|c|c|c|c|c|c|c|}
\hline \multicolumn{8}{|c|}{ Q8 } \\
\hline & & & & Frequency & Percent & Valid Percent & $\begin{array}{c}\text { Cumulative } \\
\text { Percent }\end{array}$ \\
\hline \multirow[t]{5}{*}{ Valid } & Agree & & & 1 & 2.5 & 2.5 & 2.5 \\
\hline & $\begin{array}{l}\text { Neither } \\
\text { Disagree }\end{array}$ & Agree & Nor & 2 & 5.0 & 5.0 & 7.5 \\
\hline & Disagree & & & 30 & 75.0 & 75.0 & 82.5 \\
\hline & S. Disagree & & & 7 & 17.5 & 17.5 & 100.0 \\
\hline & Total & & & 40 & 100.0 & 100.0 & \\
\hline
\end{tabular}




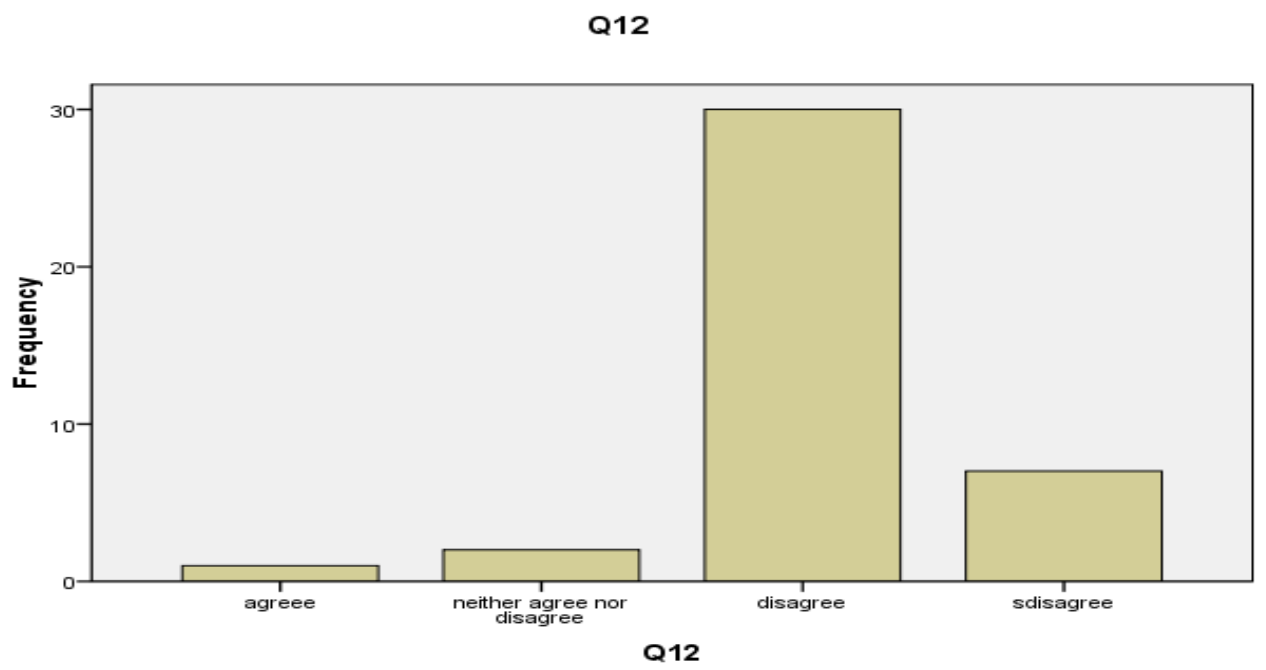

One of the biggest drawbacks of the ACR system is that peers and subordinates feedback but the employees' attitude, behavior and performance is not being taken. That helps the supervisors to put false feedback about employee.

Qno.9In the current ACR system proper training is offered to improve my deficiencies previously identified.

\section{Statistics}

\begin{tabular}{|c|c|c|}
\hline $\mathrm{N}$ & $\begin{array}{l}\text { Valid } \\
\text { Missing }\end{array}$ & 40 \\
\hline & & 4.0000 \\
\hline Mo & & 4.0 \\
\hline
\end{tabular}

\begin{tabular}{|c|c|c|c|c|c|c|c|}
\hline \multicolumn{8}{|c|}{ Q9 } \\
\hline & & & & Frequency & Percent & Valid Percent & $\begin{array}{c}\text { Cumulative } \\
\text { Percent }\end{array}$ \\
\hline \multirow[t]{5}{*}{ Valid } & Agree & & & 4 & 10.0 & 10.0 & 10.0 \\
\hline & $\begin{array}{l}\text { Neither } \\
\text { Disagree }\end{array}$ & Agree & Nor & 4 & 10.0 & 10.0 & 20.0 \\
\hline & Disagree & & & 28 & 70.0 & 70.0 & 90.0 \\
\hline & S. Disagree & & & 4 & 10.0 & 10.0 & 100.0 \\
\hline & Total & & & 40 & 100.0 & 100.0 & \\
\hline
\end{tabular}




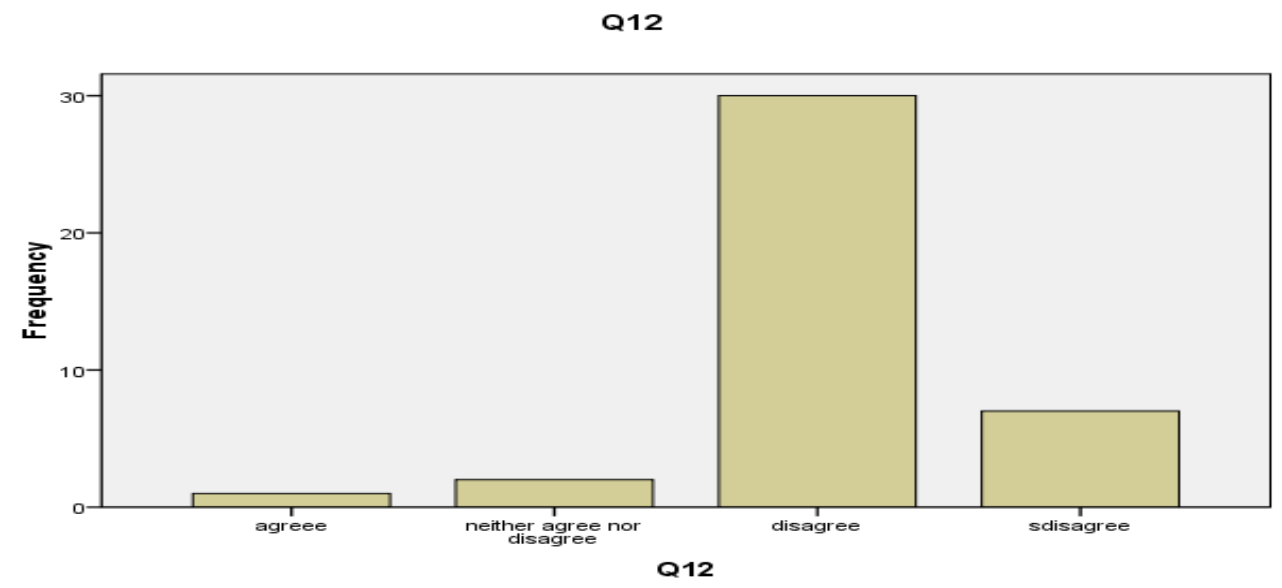

Every performance management and evaluation system has got a feedback system for the employees. Where the employees are informed about their performance during the year. While in ACR system it is kept secret.

Qno.10. I am satisfied with the current performance evaluation system (ACR).

\section{Statistics}

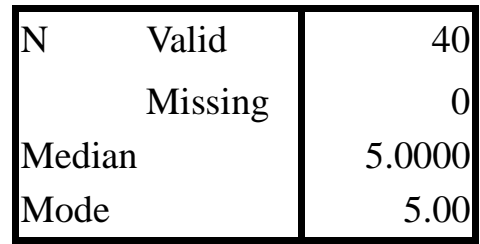

\section{Q10}

\begin{tabular}{|ll|r|r|r|r|}
\hline & & Frequency & Percent & Valid Percent & $\begin{array}{c}\text { Cumulative } \\
\text { Percent }\end{array}$ \\
\hline Valid Agree & 4 & 10.0 & 10.0 & 10.0 \\
& Neither Agree Nor & 2 & 5.0 & 5.0 & 15.0 \\
Disagree & & 4 & 10.0 & 10.0 & 25.0 \\
Disagree & 30 & 75.0 & 75.0 & 100.0 \\
Strongly Disagree & 40 & 100.0 & 100.0 & \\
Total & & & \\
\hline
\end{tabular}




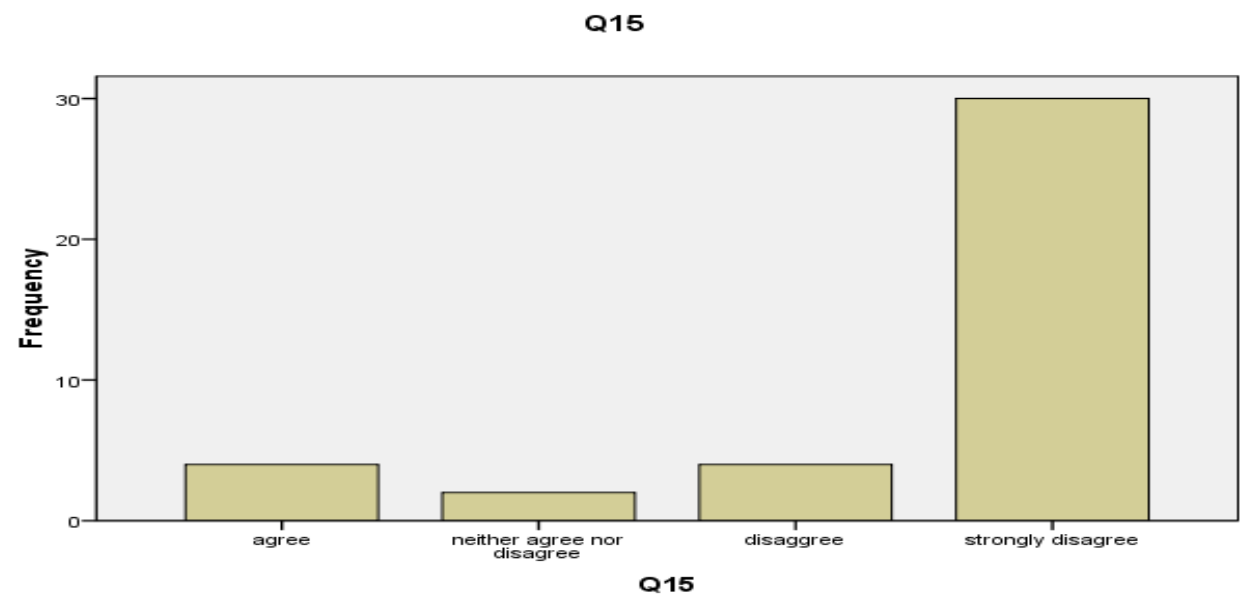

This question was strongly disagreed by most of the respondents because they were extremely dissatisfied with the current ACR system. As it is not an effective tool to be used as a performance evaluation tool.

\section{Conclusion and Recommendations}

\subsection{Conclusion}

Mostly in public sector organizations ACR system is used as a performance evaluation and management tool. No one has bothered to even bring change in the current system ACR system. AWKUM is also using ACR system without any change in it. An effective and Efficient Performance management system has many important aspects to be covered that ACR don't even bother to cover those important elements. In any performance management system career management is an important tool for the employee's performance management. All the employees must have to go through the three phase of career management that includes career exploration, career development and strategies for them. The current ACR system in AWKUM doesn't even think of these things. In AWKUM a simple ACR form is being filled by the super visors at the end of the year. Then it is send to the registrar office and kept there as a secret book. No one has access to them as it is a confidential report. It is an interesting thing to note that if an employee is evaluated and if he is not performing well then how he/she will know that his/her performance need improvement.

There is no feedback in the ACR system implemented in AWKUM. Without a proper feedback system employees will not have a clear idea how they performed in the last year. The improvement in employee performance is only possible when they are told that how he/she performed. So feedback in an effective performance management system is very important. Every employee wants recognition if his/her works hard. If an employee works hard throughout the year and his/her work is not recognized then soon his/her self motivation will fade away. Without recognition an employee can't be motivated to work hard. The recognition can be in shape of pay rise, promotion, bounce. AWKUM doesn't have this culture all the employees if they work hard or not are put in one category. Supervisor biasness is a big factor that can change the ACR report of an 
employee. If a supervisor is happy from an employee. he/she will have an excellent ACR without bothering the fact that he/she performed well or not and vice versa. Employee performance should be evaluated not only by the supervisors but also by the peers, subordinates and students. It will reduce the biasness of the supervisors.

\subsection{Recommendations}

Based on the above facts, analysis and conclusion following are few suggestions given below.

- The current ACR system should be changed with some other effective and efficient performance management system.

- Proper career management system should be design for the employees that include career exploration, career development and strategies development for the career growth.

- There should be a proper feedback system where the employees are told about their shortcoming and performance during the year. The Evaluation of the employees should not be kept secret it should be shared among the employees.

- After the evaluation of the employees proper training session should be designed for the improvement in those areas.

- Employees performance management system should be 360 degree management means that only supervisors should not be the evaluator other people like peers, subordinates and students should also be taken on board. To reduce the level of biasness that can be shown by the supervisors to the employee.

- Evaluation of the employee should not be limited to the end of the year. He/she should be evaluated throughout the year.

- Supervisor should work as coach and mentor to the employees working under him/her. After analyzing employees performance the supervisor should communicate the employee that how he/she can improve performance in specific area.

- Pay rise, promotion and bounces should be linked to the employee's performance. So that all the employee's start showing commitment to the organization goals. Through this way all the employees will have a clear idea that

\section{References} higher performance in the task assigned is the only way to get career goals.

Bandura, A. A. (1977). Self-efficacy: Toward a unifying ... In A. Bandura (Ed.), Selfefficacy in changing societies (pp. 1-45). New York: ... In J. R. Hackman (Ed.), Groups that work (and those that don't) (pp.1-14). San Francisco:

Caroline, B. \& Clive, F. (2002). The Impact of Multiple Source Feedback onManagement Development: Findings from a Longitudinal Study, Journal of Organizational Behavior, Vol. 23, No. 7 , pp. 853-867

David, K. \& Arne, L. K. (1994). Job Training in Organizations. American Sociological Review, Vol. 59, No. 4, pp. 537-546 
Dessler, G. (1993). How to Earn Your Employees' Commitment. The Academy of Management Executive (1993), Vol. 13, No. 2, Themes: Technology, Rewards, and Commitment.

Drucker, P. (1954). The Practice Of Management. New York: Harper \& Row Publishers. Farr, J. L. \& Jacobs, R. (2006). Trust Us: New Perspectives on Performance Appraisal. In Bennett, D. Woehr, \& C. Lance (Eds)., Performance Measurement: Current Perspectives and Future Challenges, pp. 321-337. Mahwah, NJ: Lawrence Erlbaum Associates.

Farr, J.L. \& Jacobs, R. (2006). Trust Us: New Perspectives on Performance Appraisal. In W. Bennett, D. Woehr, \& C. Lance (Eds)., Performance Measurement: Current Perspectives and Future Challenges, pp. 321-337. Mahwah, NJ: Lawrence Erlbaum Associates.

James, H. Stronge \& Virginia M. H. (1992). A Performance Evaluation System forProfessional Support Personnel. Educational Evaluation and Policy Analysis, Vol. 14,No. 2, pp. 175-180

Peterson, W. \& Manolakis, G. (1983). Management Training as a Troubleshooting Tool, Journal (Water Pollution Control Federation), Vol. 55, No. 8, Conference Preview Issue (Aug., 1983), pp. 1051-1056

Philips-Jones, L.L (1982).Mentors and Proteges. New York:Arbor House.

Porter, L. W. Richard, M. Steers, R. Mowday, T. \& Paul, V. B. (1974). Organizational, Commitment, job Satisfaction and turnover among psychiatric technicians. Journal of Applied Psychology, 59: 603-609

Samuel, M. N. \& Thomas, D. (2005). The Five Stages of Executive Coaching: Better Process Makes Better Practice. Journal of Business Ethics, Vol. 59, No. 4 , pp. 361-374

Yeager, S. J., Rabin, J., \& Vocino, T. (1985). Feedback and Administrative Behavior in the Public Sector, Vol. 45(5), pp. 570-575 


\section{Appendix}

\section{Research Questionnaire}

This questionnaire is based on an effort to find out the validity of employees Annual Confidential Report (ACR) and its applicability as a performance evaluation tool in Abdul Wali Khan University, Mardan. The research is being conducted on an anonymous basis and we don't ask you to provide your name or any information that will identify you. Thanks for your assistance.

\section{Instructions:}

Please Tick $(\sqrt{ })$ the boxes as per your response to the statements given below

\begin{tabular}{|c|c|c|c|c|}
\hline Strongly agree & Agree & $\begin{array}{c}\text { Neither agree } \\
\text { nor disagree }\end{array}$ & Disagree & $\begin{array}{c}\text { strongly } \\
\text { disagree }\end{array}$ \\
\hline 1 & 2 & $\mathbf{3}$ & $\mathbf{4}$ & $\mathbf{5}$ \\
\hline
\end{tabular}

\begin{tabular}{|c|c|c|c|c|c|c|}
\hline & Statements & 1 & 2 & 3 & 4 & 5 \\
\hline 1 & $\begin{array}{l}\text { The current ACR system has a significant impact on my career } \\
\text { development and career growth. }\end{array}$ & & & & & \\
\hline 2 & $\begin{array}{l}\text { The current ACR system gives me recognition for giving } \\
\text { outstanding performance. }\end{array}$ & & & & & \\
\hline 3 & $\begin{array}{l}\text { My pay and rewards are fairly and equitably linked to my } \\
\text { performance in the current ACR system. }\end{array}$ & & & & & \\
\hline 4 & $\begin{array}{l}\text { I am more motivated and produce the better expected results } \\
\text { in the current performance evaluation system (ACR). }\end{array}$ & & & & & \\
\hline 5 & $\begin{array}{l}\text { Supervisors give me advice in the current ACR system about } \\
\text { my tasks. }\end{array}$ & & & & & \\
\hline 6 & $\begin{array}{l}\text { I am satisfied with the fact that my performance in current } \\
\text { ACR system is evaluated at the end of the period and not the } \\
\text { whole year. }\end{array}$ & & & & & \\
\hline 7 & $\begin{array}{l}\text { The current ACR system is free from any kind of biasness of } \\
\text { supervisors. }\end{array}$ & & & & & \\
\hline 8 & $\begin{array}{l}\text { The current ACR system takes my feedback from the peers } \\
\text { and students about my performance. }\end{array}$ & & & & & \\
\hline 9 & $\begin{array}{l}\text { In the current ACR system proper training is offered to } \\
\text { improve my deficiencies previously identified. }\end{array}$ & & & & & \\
\hline 10 & $\begin{array}{l}\text { I am satisfied with the current performance evaluation system } \\
\text { (ACR). }\end{array}$ & & & & & \\
\hline
\end{tabular}

\section{Thanks for Your Assistance}

